İnceleme Makalesi - Review Article

\title{
Osmanlı Emeklilik Sistemi’nde Arpalık Uygulaması
}

\section{Arpalı Implementation in the Ottoman Pension System}

\author{
Metehan SAHIN* \\ (iD) 0000-0002-7922-9291
}

Sosyal Güvenlik Dergisi / Journal of Social Security

Cilt: 10 Sayı: 1 Y1l: 2020 /Volume: 10 Issue: 1 Year: 2020 Sayfa Aralığı: 185-196 Pages: 185-196

DOI: $10.32331 /$ sgd.753089

\section{ÖZ}

Emeklilik, bireylerin maluliyet veya yaş gibi çeşitli nedenlere bağlı olarak çalışma hayatından çekilmelerini ifade etmektedir. Bu dönemde, fiili çalışma karşılı̆̆ 1 alınan maaşlardan yoksun kalanların geçimlerini temin etmek ise sosyal devlet anlayışının bir gereği sayılmaktadır. Osmanlı İmparatorluğu döneminde emeklilik ile ilgili bu düzenlemelerden biri arpalık uygulamasıdır. Bu çalışmada, İbnül Emin Mahmud Kemal İnal'ın 1926 yılında Tarih-i Osmanî Mecmuası'nda yayınlanan "Arpalık" başlıklı yazısından hareketle bu maaş uygulamasının Osmanlı emeklilik sistemi içerisindeki yerinin incelenmesi amaçlanmaktadır. Arpalık, başlangıçta kelime anlamına uygun olarak özellikle seyfiye ricalindeki bazı devlet büyüklerinin hayvanları için verilen tahsisatı ifade etmiştir. Ancak zamanla arpalığın ihtiva ettiği anlamın ve uygulama şeklinin değiştiği anlaşılmaktadır. Araştırma sonuçlarına göre devlet görevlileri için geçerli bir uygulama olarak arpalığın, bireylerin hem çalışma dönemlerinde ek bir gelir hem de emeklilik dönemlerinde tekâ'üdiye (emekli maaşı) olarak verildiği görülmektedir. Ayrıca genel kanaatin aksine Osmanlı İmparatorluğu idaresinin birçok Avrupalı devletten önce kanunlar ve irade-i seniyyeler gibi yöntemlerle emeklilik ile ilgili düzenlemeleri hayata geçirdiği anlaşılmaktadır.

\begin{abstract}
Pension means that individuals retreat from the work life because of the causes like disability and age. In this period, it is accepted as a necessity of welfare state mentality that to provide the people's living who lost their wages they got in exchange for actual working. Arpalık is one of the regulations about pension during Ottoman Empire. This study aims to invetstigate the position of this wage implementation in Ottoman pension system by the İbnül Emin Mahmud Kemal İnal's article entitled Arpalık which is published in Tarih-i Osmanî Mecmuası in 1926. At first, in accordance with meaning of the word, arpalık expressed the an appropriation for given to some military class statesmans' animals. But it is understanding that arpalık's meaning and implementation way changed with time. According to result of research, it is seen that as an implementation for government officials arpalık was given to individuals both as an additional income in their work life and as tekâ'üdiye (pensionable salary) in their pension periods. Against to general opinion, it is also seen that Ottoman Empire administration put on practice the regulations about pension by the methods like laws and irade-i seniyye earlier than the European states.
\end{abstract}

Anahtar Sözcükler: Osmanlı İmparatorluğu, arpalık, emeklilik sistemi

Keywords: Ottoman Empire, arpalık, pension system

Önerilen atıf şekli: Şahin, M. (2020). Osmanlı Emeklilik Sistemi’nde Arpalık Uygulaması. Sosyal Güvenlik Dergisi (Journal of Social Security). 10(1). 185-196.

\footnotetext{
* Arş. Gör., Tokat Gaziosmanpaşa Üniversitesi, İktisadi ve İdari Bilimler Fakültesi, İktisat Bölümü, metehan.sahin@gop.edu.tr
} 


\section{GİRIŞ}

İnsanoğlu, varoluşundan itibaren olası tehlikelere karşı korunma ve sürekli geçimini sağlayacak vasıtaları temin etme ihtiyacı hissetmekte; bu ihtiyacın karşılanmasına yönelik çabalar tarih boyunca çok çeşitli yardımlaşma ve dayanışma sistemlerini ortaya çıkarmaktadır. Artık evrensel bir ilke ve medeniyet göstergesi durumuna gelen sosyal güvenlik kavramı da insanların karşılaşabilecekleri ve hayatları için tehlikeli sayılabilecek vakalara karşı bir güvence arayışından doğmaktadır (Türkal, 1999: 4).

Sosyal güvenlik sistemlerinin tarihi seyri incelendiğinde Sanayi Devrimi'nin bu süreçte bir yol ayrımı oluşturduğu, önceden kişisel, karşılıklı yardım temeline dayanan bir yapı mevcut iken, bu olaydan sonra, modern anlamda sosyal güvenlik sistemlerine geçildiği belirtilmektedir (Güvercin, 2004: 90). Pek çok tanımı bulunan sosyal güvenlik kavramı, Talas (1955)'e göre fizyolojik, sosyolojik veya bir mesleki risk nedeniyle geliri sürekli ya da geçici olarak kesilmiş bulunanların yaşama-geçinme ihtiyaçlarını karşılayan sistem olarak adlandırılmaktadır. Gerek günümüzde gerekse geçmişte ülkelerin sosyal güvenlik harcamaları içerisinde en büyük payı ise emeklilik sigortası kapsamında yapılan harcamalar, emekli aylığı ödemeleri oluşturmaktadır.

Yapılan çalışmada belirli dönemlerde belirli konularda ve çeşitli kişilere tevcih kılınmış olsa da Osmanlı İmparatorluğu'nun emeklilik sisteminde önemli bir yeri olduğu anlaşılan arpalık uygulamasının özellikleri incelenmektedir. Literatürde genel anlamda Türk sosyal güvenlik sisteminin tarihini (Türkal, 1999; Güvercin, 2004; Şenocak, 2009; Orhan, 2015) ve Osmanlı İmparatorluğu'ndaki emeklilik sistemini inceleyen (Martal, 1999, 2008; Özger, 2011a, 2011b; Manav, 2014, 2017) çalışmalar bulunmakta, ancak arpalık sistemine özgü pek fazla çalışma bulunmamaktadır. Dolayısıyla çalışmada bu konuda mevcut bir eksikliğin giderilmesine katkı sağlanması amaçlanmaktadır. Bu amaç doğrultusunda, ilk bölümde Osmanlı İmparatorluğu'nda sosyal güvenlik kavramı analiz edilecek, ikinci bölümde Osmanlı emeklilik sistemi genel yapısı ve özellikleri itibariyle incelenecek, üçüncü bölümde arpalık uygulamasının Osmanlı emeklilik sistemi içerisindeki konumu ve önemi İbnülemin Mahmud Kemal İnal'ın, 1926 yılında Tarih-i Osmanî Mecmuası'nda yayınlanan "Arpalık" başlıklı yazısından hareketle tartışılacaktır. Dördüncü bölümde ise sonuç ve değerlendirmelere yer verilecektir.

\section{I- OSMANLI IMPARATORLUĞU'NDA SOSYAL GÜVENLIK}

Sosyal güvenlik, ilk insan topluluklarının başlangıcından itibaren ihtiyacı hissedilen bir kavram olarak kabul edilmektedir. Belirli dönemlerde; ekonomik, sosyal şartlar ve çoğu zamanda dini inanışlara göre bu ihtiyacın temin edilmeye çalışıldığı, önce kabile sonrasında ise aile içi yardımlaşma biçiminde devam eden doğal sosyal güvenlik yöntemlerinin, zaman ve ekonomik şartlara göre değişmiş olmakla birlikte yüzyıllar boyu önemini koruduğu görülmektedir (Dilik, 1998: 41-42). Toplumlarda sosyal güvenlik ihtiyacını doğuran nedenlere tehlike (risk) adı verilmekte; bu tehlikeler, hastalık, yaşlılık, maluliyet, kazalar ve ölüm gibi fiziki tehlikeler, aile gelirinin çocuk sayısına bağlı olarak yetersizliği ve işsizlik gibi iktisadi tehlikeler şeklinde sınıflandırılmaktadır. Her iki gruptaki tehlikeler, nüfus artış hızı, ölüm oranları ve yaş yapısı gibi demografik, işgücünün sektörel dağılımı ve mesleki durum gibi ekonomik, örf-adetler ve din gibi sosyolojik, eğitim ve sağlık gibi kültürel koşullarla çok yakından ilişkilidir. Koşulların bireyler arasındaki farklılığı ise söz konusu tehlikelerin varlık veya yokluklarında değil, nispeten azlık veya çokluklarında, etkilerinin uzun veya kısa süreli olmasında etkili sayılmaktadır (Yazgan, 1972: 191-192). Sosyal güvenlik sistemi, sosyal sigorta müesseselerinden ve kamu eliyle yapılan sosyal güvenlik harcamalarından oluşmaktadır. Sosyal sigorta kurumlarında, işçi, memur, serbest meslek 
sahibi vb. bireyler ödedikleri prim karşıllğı olarak tehlikelere karşı korunmaktadır. Kimsesiz çocuklar, bakıma muhtaç yaşl1, sakat ve maluller gibi gelir getiren iktisadi bir uğraşı bulunmayan bireylere ise kamu sosyal güvenlik harcamaları yoluyla geçinme imkânları sağlanmaktadır (Tabakoğlu, 2005: 319-320).

Bugünkü anlamda sosyal güvenlik sisteminin işlevleri Osmanlı klasik döneminde vakıflar eliyle yerine getirilmektedir. Osmanlı İmparatorluğu'nda vakıfların; yolcular ve hac yolunda parasız kalanlara yardım, kimsesiz, yaşlı ve çocukların barındırılması, darüşşifa, hastane açılması ve işletilmesi, dükkân açmak isteyenlere, ticaret ve sanatta işi bozulanlara yardım, fakir yaşlı ve çocuklara elbise ve yiyecek sağlanması; bilhassa emeklilik sistemi uygulamaları içerisinde değerlendirilebilecek, dul ve yetimlerin geçindirilmesi, harp malulleri ve gazilerine yardım ile ağır işlerde çalışanlara ve esnafa yaşlılık ve sakatlık durumunda yaşlılık aylığına benzer gelir sağlanması gibi sosyal güvenlik ile ilgili olarak çeşitli amaç ya da faaliyet alanlarına sahip oldukları bilinmektedir (Dilik, 1998: 68). Esnaf birlikleri ise oluşturdukları fonlar aracılığıyla çalıştırdıkları işçilere ve diğer esnafa gereken durumlarda yardım etmekte, esnaflar tarafindan kurulan bu birlikler ve meydana getirdikleri yardım sandıkları bugünkü anlamda bir sosyal güvenlik sistemini anımsatmaktadır (Türkal, 1999: 43). Nitekim loncalar tarafindan kurulmuş olan orta sandığı ya da teavün sandığ ile muhtaç duruma düşmüş esnaf ve esnaf ailelerine yardım edilirken, yaşlanarak işini terk etmiş ve muhtaç durumuma düşmüş ustaların, bir sakatlık veya hastalık nedeniyle iş göremez hale gelen; çırak, kalfa ve usta gibi tüm meslek mensuplarının geçimleri sağlanmaktadır (Dilik, 1998: 62). Osmanlı İmparatorluğu döneminde ferdiyetçilikten ziyade toplumsalcılık hâkim olduğundan belirli bir grup ya da zümreye ait bireyler arasında yardımlaşma ve dayanışma temin eden müesseseler ilerleyen süreçte çeşitli şekillerde kurumsallaşabilmektedir. $\mathrm{Bu}$ kapsamda düşünülebilecek sosyal güvenlik müesseseleri ise şu şekilde sıralanmaktadır (Özcan, 1999: 111-113):

- Orta Sandıkları: Yeniçeriler arasında dayanışma tesis etmek, ihtiyaçlı duruma düşenlerin kendilerine ve ailelerine yardım etmek maksadıyla geliri ulufe dağıtımı sırasında \%3-5 oranında alınan aidatlar ile bekâr olarak ölen yeniçerilerin geride bıraktıklarından ve bağışlardan sağlanan kurumdur.

- Esnaf Sandıkları: İmparatorluk esnafının rekabetten çok iş birliği ve karşılıklı kontrole dayanan bir ilişki içerisinde bulunmasının sonucu olarak, geliri esnaftan bazı kimselerin doğrudan veya vasiyetle yaptıkları bağışlar, esnaflık silsilesinin (çırak, kalfa, usta hiyerarşisinin) her aşamasındaki ödemeler, nakit ve gayrimenkullerin işletilmesinden sağlanan hâsılat ile belirli aralıklarla yapılan tahsisattan oluşan kurumdur.

- Avârız Vakıfları: Köy ve mahallelerde halkın bazı ortak sorumluluklarının ve çeşitli ihtiyaçlarının karşılanması için kurulan, geliri kişilerin türlü vesilelerle yaptıkları bağışlar ile vakfın tasarrufunda bulunan nakit veya gayrimenkullerden kazanılan hâsılattan oluşan kurumdur.

- Aile Vakıfları: Bir ailenin sahibi olduğu servetten, vakfın kurucusunun evlatları ile bunlardan sonraki nesillerinin, vakfın sağladığı imkânlar çerçevesinde asgari seviyede de olsa bir iş ve gelire sahip olmaları amacıyla oluşan kurumdur.

- Arpalıklar: Çoğunlukla devlet görevlilerini kapsayan bir sosyal güvenlik kurumu olarak düşünülebilecek bu uygulamanın ilmiye ve seyfiye ricalinin görevleri sırasında ek bir gelir kaynağı olduğu gibi bir nevi işsizlik sigortası vazifesini de yerine getirdiği, daha sonraları ise bir emeklilik maaşı hüviyeti kazandığı anlaşılmaktadır. 
- Âkile Müessesesi: Başlangıçta kişilerin âkile denilen yakın çevreleri içerisinde birbirlerinin kontrolünü sağlamaya yönelik bir mekanizma olarak tasavvur edilebilecek bu kurum, işlediği suç sebebiyle yargı kararına bağlı olarak tazminat ödemekle sorumlu tutulan kişinin, bu sorumluluğu bahse konu yakın çevresi ile paylaşmak durumunda kalması sonucunda mali dayanışma halini almaktadır.

Avrupa'da, sosyal güvenlik hakları adına, 16. yüzyıldan itibaren kiliselerin yanı sıra devletin yardım kurumları oluşturmasından 18 . yüzyıldaki felsefî düşüncelerde meydana gelen değişimlere kadar bazı gelişmeler görülmüş, kamu yardımlarından yararlanmanın bir hak olduğu 1793 tarihli İnsan Hakları Bildirisi'nde yer almış ancak 19. yüzyılın başlarına kadar bu konuda somut bir adım atılamamıştır (Güvercin, 2004: 90). Bireylerin sosyal olarak korunmasının, Sanayi Devrimi ile birlikte 18. yüzyıldan itibaren daha büyük bir önem kazandığı anlaşılmaktadır. Zira Sanayi Devrimi’nin getirmiş olduğu kapitalist üretim biçimi sonucunda şehirlerde oluşan büyük işçi sınıfları ve geleneksel üretim yöntemlerinde yaşanan hızla dönüşüm gibi nedenlere bağlı olarak ağırlaşan çalışma koşulları yeni sosyal politika önlemlerinin alınmasını zorunlu kılmaktadır (Erdoğan, 2018: 19). Kabile içi yardımlaşma, aile içi dayanışma ve yardımlaşma, dini inanış ve diğer güdülerle kişi veya devlet eliyle fakirlere yardımlar ve orta çağ döneminde mesleki kuruluşlar yoluyla ihtiyaç sahiplerine yapılan yardımlar gibi geleneksel sosyal güvenlik yöntemleri, Sanayi Devrimi sonrasındaki sosyal, siyasal ve iktisadi şartların ortaya çıkardığı yeni durumda mevut ihtiyaçlara cevap veremez hale gelmiş, büyük ölçüde önemini kaybetmiştir. Bu noktadan hareketle de sosyal güvenlik ihtiyacının insanlık tarihi kadar eski olmasına rağmen bir sistem olarak doğuşunun Sanayi Devrimi’nin gerçekleşmesi ile mümkün olabildiği ifade edilmektedir (Akyıldız, 1999: 197). Osmanlı İmparatorluğu'nun ise henüz 19. yüzyılda çıkardığı iradelerin, maliye defterlerinin ve Meclis-i Vükela mazbataları gibi arşiv malzemesinin, devlet hizmetinde çalışanlar, bu kişilerin dul ve yetimleri ile korunmaya muhtaç diğer bireylerle ilgili düzenlemelerini ve Osmanlı'da sosyal devlet anlayışının gelişimini açık bir şekilde yansıttığ kabul edilmektedir (Martal, 2008: 423).

Osmanlı sosyal güvenlik sistemini incelerken klasik dönem için devlet görevlileri (askerî zümre) ve halk kesimi (reaya) ayrımı yapabilmek mümkün iken; Gülhâne Hatt-1 Hümâyûnu'nun ilanını takip eden dönemde genel merkezileştirme ve devletleştirme eğiliminin de etkisiyle devlet bürokrasisinin sosyal güvenlik sistemine hâkim olduğu görülmektedir (Tabakoğlu, 2014: 469).

\section{II- OSMANLI İMPARATORLUĞU'NDA EMEKLİLIKK}

Sözlükte oturmak manasına gelen ku'ûd kelimesinden türetildiği ifade edilen tekaüt (tekâ'üd) kelimesi ihtiyarlık veya sakatlık sebebiyle hizmet ve vazifesini terk ile istirâhata çekilmeyi ifade etmekte ve günümüzde emeklilik, emekliye ayrılma kelimelerine karşılık gelmektedir (Sami, 2017: 333). Benzer şekilde mütekâ'id "memuriyyet ve hizmetten çekilip, hizmet müddetine göre maaş alan" başka bir ifadeyle emekli yerine kullanılan bir terimdir (Pakalın, 1993: 638-639). Osmanlı İmparatorluğu'nda askerî zümreyi oluşturan seyfiye, idare amirleri ve memurlar sınıfını teşkil eden kalemiye ile din ve eğitim işlerinde görevli ilmiye mensuplarına malullük ya da sakatlık durumlarında ihtiyaçlarını karşılayacak miktarda tekâ'üdiye denilen bir maaş bağlanır veya bir yerin geliri tahsis edilirdi. 19. yüzyılın ikinci yarısında kurulan emekli sandıklarından önce, bazı durumlara göre miktarı değişen bu maaşlar devletçe verilen bir lütuf olarak nitelendirilmektedir (Martal, 2008: 424). Yaş1 nedeniyle iş yapamayacak duruma gelen, idarî ve askerî aczi anlaşılan ya da gazaba uğrayarak azledilen bir vezir emekli edilerek, kendisine geçimini sağlayacak kadar has veya bir bölgenin mukataasından aylık belirli bir para ödenmektedir. Bazı hallerde vezirler tekrar 
Osmanlı Emeklilik Sistemi'nde Arpalık Uygulaması

göreve tayin edilebildiği gibi, vezir sayısının arttığı dönemlerde bir kısmının zorunlu olarak emekliliğe sevk edildiği bilinmektedir (İpşirli, 2011: 340).

\section{A- Tanzimat Dönemi Öncesinde Osmanlı İmparatorluğu'nda Emeklilik}

Klasik dönemde emeklilik konusunu, Fatih Kanunnamesi'nde ele alınarak, devlet adamlarından her birine emeklilik döneminde verilecek akçe miktarının sistemleştirildiği anlaşılmaktadır. Buna göre, sancak beylerinin altmış bin, mâl defterdârlarının seksen bin, baş defterdârın doksan bin, beylerbeyilerin yüz bin ve vezîr-i a'zamın yüz elli bin akçe senelik ile mütekâ'id olmaları öngörülmektedir (Özcan, 2003: 20). Kanuni Sultan Süleyman döneminde vezirlik yapan Lütfi Paşa, Âsafnâme'de devlet hazinesinin saltanatın devamının şartı olmasına binaen hazine işlerini umur-1 mühimmeden saymakta, ancak döneminde hazineyi düzensiz ve noksan bulduğunu belirtmektedir. Eserinde emeklilik konusuna da değinen Lütfi Paşa, tîmâr ile tekâ'üd olursa sancak beylerine elli bin, defterdarlara altmış bin, beylerbeylerine seksen bin ve vezirlere yüz yirmi bin akçe verilmesinin kanun olduğunu, fazlasının verilmemesi gerektiğini belirtmektedir (Kütükoğlu, 1991: 34-38). 17. yüzyıla ait olduğu bilinen Eyyubî Efendi Kanunnamesi'nde de emeklilik konularına yer verildiği görülmektedir. Buna göre eserde, 1660 yılı divan defterinde mevâcib-i mütekâidîn içerisinde anılan Enderun mensubu ve ağalardan 55 kișinin emekli olduğu ve bunların yevmiyelerinin üç yük 9,950 akçe ve senelik ücretleri toplamının ise 12 yük 79,800 akçe tuttuğu yer almaktadır (Aykanat, 2015: 212).

Emeklilik uygulaması ilmiye mensupları arasında yaygın olmakla birlikte, askeri zümrenin ikinci grubu olan kapıkulları ve özellikle yeniçeriler için de önem taşımaktadır. 16. yüzyılın ikinci yarısı içinde neferlikten tekâ'üd eden bir yeniçerinin maaşı günde 3 akçe iken, bir süre sonra bu miktar en az 4 en fazla 8 akçeye kadar yükseltilmiştir. Fiilen hizmet gören ve emekliye ayrılanların sayısının artması üzerine 18. yüzyıl boyunca bazı düzenlemelere gidilse de ortaya çıkan karışıklıkların Yeniçeri Ocağı'nın kapatılmasına kadar sürdüğü anlaşılmaktadır (İpşirli, 2011: 341). Kapıkullarının emekli olabilmesi için herhangi bir yaş sınırı bulunmamakta; sadece amelmande olarak adlandırılan iş yapamaz hale gelenleri emekliye ayrılabilmektedir. Bu hakkı kazanabilmek için ise silahaltında yaşlanmış ya da aldığı yaralardan dolayı hizmete iktidarı kalmamıș olması lazım gelmektedir. Yine bu kișilere emekli anlamına gelen mütekâ'id veya otrak denildiği bilinmektedir (Tabakoğlu, 2014: 470).

18. yüzyıl sonlarında III. Selim tarafından kurulan Nizâm-1 Cedîd Ordusu mensuplarının emeklilikleri, ilan edilen bir başka kararnamede ele alınmaktadır. Kanuna göre Nizâm-1 Cedîd askerlerinin talim yaptıkları yer olan Levend Çiftliği Ocağı'ndan tekâ'üde ayrılanların emekli maaşlarını karşılamak üzere; Kütahya, Menteşe, Ankara, Aydın, Beyşehri, Çankırı (Kangırı), Aksaray ve Köstendil sancaklarında mevcut 425 adet timar ve zeamet tevcih edilmektedir. Emekli olan askerlerden hayatını kaybedenlerin maaşları, ihtiyaç durumunun ileri seviyede olması halinde çocuklarına devredilirken; genellikle diğer ocaklarda olduğu gibi çocuklarına verilmeyip hazineye aktarılmaktadır (Özger, 2011a: 97-98).

Osmanlı İmparatorluğu'nun 19. yüzyıl sonlarına doğru, askeri kurumlar başta olmak üzere diğer kamu hizmetlerinde çalışanların ve aile bireylerinin maluliyet, yaşlılık ve ölüm gibi sosyal güvenlik kapsamına giren konularda Avrupalı muasırlarından önce çeşitli düzenlemeler yaptıkları ifade edilmektedir (Martal, 2008: 429). Bu noktada, 1826 yılında Yeniçeri Ocağı'nın tamamen kaldırılmasından sonra kurulan Asâkir-i Mansûre-i Muhammediye Ordusu Osmanlı emeklilik sisteminde farklılaşmayı gösteren önemli bir adım olarak değerlendirilmektedir. Yeni kurulan ordu için ilan edilen kanunnamede, tekâ'üdlük verilecek kimsenin durumunun Serasker Paşa ve Nazır'1n ortaklaşa olarak Bâb-1 Âli'ye arz 
edilmesi, Hekimbaşı Efendi tarafından amelden sukûtu keyfiyetinin muayene edilmesi, dîvân-ı sadr-ı a'zaminin uygun görmesine binaen hidmet-i defterîye havale olunarak îcâb eden tekâ'üdlüğ̈̈ iktizâsına göre tevcih ve senedi tanzîm olunmak, yani Tekâ'üdlük Beratı verilmesi gerektiği belirtilmektedir (Keleş, 2006: 233). Kanun düşkün ve ihtiyar olanlara aldıkları maaşın yarısı, savaşta yaralananlara ise maaşlarının üçte ikisi oranında emekli maaşı bağlanmasını öngörmektedir. Askerin künyesinin, nerede olduğu ve kaç kuruş maaş ile emekli olacağının yazılı olduğu tekâ'üd beratları, emekli maaşlarının sipariş veya havale ile bilinmeyen kimselere verilmemesi; taşrada bulunanların ya kendilerinin ya da mahkemenin verdiği ilamla belirtilen kişinin, İstanbul'da oturanların ise bizzat kendilerinin emekli maaşlarını alabilmesi; maaş sahiplerinin her üç senede bir kez hayatta olduklarını ispat etmeleri, hayatta olduklarını ispat edemeyenlerin maaşlarının kesilmesi gibi özelliklere sahiptir. Dolayısıyla getirilen yenilik, emeklilik beratlarının ilk defa verilmesinde değil bunun geliştirilen bir sistem içerisinde dağıtımının devam ettirilmesinde görülmektedir (Öztürk, 1983: 2-3).

\section{B- Tanzimat Dönemi ve Sonrasında Osmanlı İmparatorluğu'nda Emeklilik}

1838 yılına gelindiğinde, II. Mahmud'un merkeziyetçi reformlarının bir unsuru olarak, gelir ve giderlerin merkezileştirilmesi amaciyla bütün memurlara maaş verilmesi kararlaştırılmakta; böylelikle, tevcihat ve tahsisat sisteminden düzenli maaş sistemine geçiş yapılmaktadır (Martal, 1999: 2). 1839 yılında ilan edilen Tanzimat Fermanı diğer birçok alan ile birlikte emeklilik sistemi ile ilgili de birtakım düzenlemeler getirmektedir. Örneğin, bu döneme kadar emeklilik sistemi içerisinde önemli bir yer tutan arpalık uygulaması, Tanzimat'tan sonra kaldırılırken yerine, emekliye ayrılan adliye mensupları gibi bürokratlara mazuliyet akçesi, ilmiye zümresine de tarik maaşı verilmeye başlanmaktadır. Ayrıca bir ilmiye ve adliye tekâ'üd sandığı oluşturularak emekli olan ilmiye mensuplarına, kadılara ve bu kişilerin vefatından sonra da ailelerine maaş tahsis edilmesi kararlaştırılmaktadır (Tabakoğlu, 2014: 470). Tekâ'üd sandıklarının kurulmasını kolaylaştıran en önemli faktörün, devlet memurlarının Tanzimat Fermanı ile düzenli maşsa geçirilmesi olduğu savunulmaktadır. Zira düzenli şekilde ödenecek memur maaşları, aynı zamanda, uygulanması düşünülen primli rejimde, düzenli şekilde ödenecek emekli maaşları için prim kaynağ1 teşkil etmektedir (Orhan, 2015: 196).

Nizamiye Askerleri ${ }^{1}$ nefer ve zabitleri arasından askerlik hizmetini yapmalarına engel oluşturacak şekilde hasta, sakat ve yaşı ilerlemiş olanların emekli edilmeleri ile vefat edenlerinin ailelerine uygun bir maaşın verilmesi Sultan Abdülaziz dönemi boyunca da devam etmekte; Ümerâ ve Zâbitân-ı Askeriyye Mütekâidîni Eytâmına Tahsîs Kılınacak Maaşlara ve Buna Karşılık Tutulacak Mebâliğin İâre-i Mahsûsuna Dâir Nizâmnâme ile birtakım esaslar uygulamaya konulmaktadır. Buna göre; Dâr-1 Şûra'nın geride kalanların alacağı maaş miktarını belirleyebilmesi için taşrada bulunan emeklilerden vefat edenlerin vefat tarihleri ve ailelerine dair bilgiler teferruatlı ilmühaber ve emeklilik beratları ile birlikte kaza meclisine bildirilecek, çocuklara verilecek maaş babalarının emekli maaşı nispetinde hesaplanacak, bu maaşı erkek çocukları yirmi yaşına, kız çocukları evleninceye kadar, çocuklar arasından iş yapmasına engel hastalığı olanlar ise ömür boyu alabilecek, çocuk bulunmayıp geride kalan yalnızca valide ve hanımları varsa onlar da maaştan yararlanabileceklerdir (Ünal, 2006: 163-165). Verilen maaşlar Mütekaidin Eytamı Sandığı'ndan ödenmekte; sandığın sermayesi rütbeleri terfi edecek zabitlerin birer aylık maaş

11843 Eylül'de yayınlanan Askerî Nizamnâme ile biri 5 yıllık Nizamiye ve diğeri 7 yıllık Redif olacak şekilde iki askerî sınıf oluşturulmuş; bu tarihten itibaren düzenli orduya Asâkir-i Mansûre ya da Asâkir-i Muntazama yerine Asâkir-i Nizâmiye denilmiştir (Ünal, 2006: 27). 
farkları ile o zamana kadar emekliye ayrılmış ve o zamandan sonra emekliye ayrılacakların maaşların daimî olarak \%2 kesilmesi yoluyla karşılanmaktadır (Özger, 2011a: 109-110). Uygulama kanunu Asâkir-i Berriye-i Mülükâne Tekâüd Kanunnâmesi 1869 yılı haziran ayında yayınlanan Askerî Tekâ'üd Sandığı'nı tophane, jandarma ve bahriye kuvvetlerinde kurulan sandıklar takip etmiş ancak emekli, dul ve yetimlerin ihtiyaçlarına tam anlamıyla cevap verilememesi ve uygulamada yaşanan sorunlar sebebiyle II. Abdülhamit'in iradesine uygun olarak tüm askeri sandıkların 1886 yılında Umum Askerî Tekâ'üd Sandığı altında birleştirilmesine karar verilmiştir (Orhan, 2015: 198-199).

II. Abdülhamid'in döneminde Batılı devletlerde ortaya çıkmakta olan türden bir mülkiye personel sistemi oluşturmak için gerekli düzenlemeleri hayata geçirdiği bilinmektedir. $\mathrm{Bu}$ süreç 1877 senesinde, bu tarihten sonra atanacak adayların seçiminde temel rol oynayacak sicil kayıtları anlamına gelen- sicil-i ahval'in tutulmasıyla başlamakta, önemli bir diğer adım olarak 1880'lerde kabul edilen ve sonraları birçok kez değiştirilen "memurin-i mülkiyenin terakki ve tekâ’üd kararnamesi”nin yayınlanması görülmektedir. Çünkü bu kararname uyarınca Osmanlılar, ücretlerde yapılacak kesintilerle finanse edilen muasırlarına benzer bir tekâ'üd sandığı oluşturmak için ilk adımı atmış bulunmaktadır (Findley, 2011: 26). Elbette bu adım, askerî zümre mensupları dışındaki devlet memurlarını kapsaması bakımından ilk sayılmaktadır. Esasen bu adımdan önce askeri zümrede olduğu gibi ilmiye sınıfı mensuplarından vefat edenlerin aileleri için Eytam ve Eramil-i İlmiye İaşe Sandığı kurulmuş, ancak zaman içerisinde bu sandığın gelişen ihtiyaçlara cevap verememesi üzerine müstakil bir sandığın oluşturulması gerekli görülmüştür (Orhan, 2015: 200). Dolayısıyla, 1876 yılında yürürlüğe giren Kânûn-1 Esâsî’nin 39. Maddesinde yer alan “...hüsn-ü hareket ve istikamet ashabindan olanlar ve devletce bir sebeb-i zaruriye mebni infisal edenler [zaruri bir nedenden ötürü memuriyetten ayrilanlar] nizam-ı mahsusunda tayin olunacağl vechle terakkiyata ve tekâ'üd ve mazuliyet maaşlarına nail olacaklardır." hükmüne dayanarak 4 Eylül 1881 yılında "Mülkiye Tekâ'üd Sandığı" kurulmuştur. Kurulan bu sistemden yararlanma, emekli maaşı alma hakkı ise mülki hizmetlerde bulundukları sırada maaşlarından \%5 aidat kesilerek sandık sermayesinin teminini sağlayan ilmiye memurlarına verilmiştir (Doğan, 2013: 47). Kânûn-1 Esâsî'nin ilanını takip eden yıllarda kurulan tekâ'üd sandıklarının nizamnameleri incelendiğinde birçok memuriyet kadrosuna dair ve farklı içeriklere sahip düzenlemelerin gerçekleştirildiği anlaşılmaktadır. 1876 yılı ve sonrasında Telgraf ve Posta Memur, Kâtip ve Hademelerine Ait Tekâ'üd Sandığı, Rüsumat Memur ve Hizmetlileri Tekâ'üd Sandığı, İdare-i Mahsusa (Seyr-i Sefain) Tekâ'üd Sandığı, İlmiye Tekâ’üd Sandığı ve Hicaz Demiryolları Memur ve Hizmetlileri Tekâ’üd Sandığı gibi sandıklar kurulmuş (Aykanat, 2015: 226); memur tekâ'üd sandıklarının iştirakçilerine sağladığı en önemli sosyal güvenlik yardımı belirli bir hizmet süresini doldurarak veya malulen emekli sayılanlara sundukları emekli maaşı olmuştur.

\section{III- OSMANLI IMPARATORLUĞU EMEKLILIIK SISTEMI'NDE ARPALIK}

Arpalığın ne amaçla ve ne zaman oluşturulduğu, başlangıçta kimlere tevcih edildiği hakkında hem ayrıntılı bir kayda tesadüf edilemediği hem de bu konuda esaslı bir araştırma yapılmadığı ifade edilmektedir. Bir başka deyişle, imparatorluğun kuruluş devrinden bahsederek, 16. yüzyıla kadarki siyasi, askeri ve iktisadi/mali olayları bildiren tarihi kaynaklarda arpalık ve bunun verilme şekli neredeyse hiç mevzubahis edilmemekte, eserler o asırlara ait olsa dahi nispeten az veya eksik bilgi verildiği savunulmaktadır (Gökbilgin, 1978: 592).

Arpalık, kelime anlamı olarak, arpa ile ilgili yani bazı devlet büyüklerinin ve atlarla savaşa katılan kuvvetlerin hayvanlarına verilen arpa parasını ifade ederken zamanla ayni ve nakdi 
tahsisatı belirten bir terim olarak kullanılmaya başlamış, ilk uygulama dönemlerinde özellikle seyfiye ricaline verilmiştir (Baltac1, 1991: 392). Yapılan araştırmanın hareket noktası kabul edilen yazısında İbnülemin Mahmud Kemal (İnal) "filan sancak yahut filan kaza, filan zâta ber vech-i arpalık tevcih oldundu denilir ki o sancak ve kazanın gelirinden bir miktarı o zâta tahsis edilirdi” sözleriyle arpalık uygulamasının ihtiva ettiği anlama değinirken; arpalığın, zeamet ve tımar gibi mukayyed (bir kişi veya kesime kayıtlı) olmayıp zevat-1 muhtelifeye verilebildiğini bildirmektedir. Örneğin, sadaretten azil ve tekâ'üd edilen vezirlere, harpte hüsn-ü hizmet gösterenlere, eşkıyalıkla mücadele edenlere ve sefere memur olanlara (azledilmiş iseler), bir mahallin muhafazasına, bir kalenin tamiri için görevlendirilenlere ve diğer zevata bir yahut birçok sancak arpalık olarak verilebilmektedir (İnal, 1926: 276-277). Dolayısıyla arpalık, muhtelif zamanlarda, devlet tarafından, farklı uygulama biçimlerine göre, belli başlı yöneticilere, saray mensuplarına ve bir kısım yüksek rütbeli ilmiye ricaline görevdeyken maaşlarına ek olarak, herhangi bir nedenle görevlerinden ayrıldıktan sonra ise mazuliyet veya tekâ'üd maaşı şeklinde verilen bir tahsisat olarak tanımlanabilmektedir (Özger, 2011a, 89-90).

İnal'ın (1926) ifadesiyle “Tımar ve ze'âmet pek mu'teber olduğundan, arpalık ve has ve başmaklık namıyla bir ferde verilemezdi. Dergâh-1 'Âli kapıcıbaşılardan tecrübekâr ve şâyân-1 i’tibâr oldukları halde de arpalıkları nihayet 19999 akçe olabilip ze’âmet derecesine irtikâ etmemek [yükselmemek] için bir akçe tezyîd edilemediği [artırılamadığı] gibi padişahların haseki kadınlarına başmaklık namıla me'aş tahsisi iktizâ ettikte [gerektikçe] havâss-1 hümâyun kurasından yine 19999 akçeye kadar ta'yîn edilip yirmi bin akçeye iblâğı [çıkarılması]" mümkün olamazdı. Gelibolulu Mustafa Âli (vefâtı 1600) tarafindan bir dünya tarihi olarak yazılan Künhü'l Ahbâr, arpalık hususunda en eski ve en itimada şayan kaynak kabul edilmektedir (Gökbilgin, 1978, 593). Bu eserde Âli, özellikle yetmiş beş bin akçe yazan arpalık ve zeametle iltifat ve rağbetlerin zümre-i ulemâdan vezîr-i âzam ve Şeyhu'l İslâm'a, bunlardan sonra kazaskerler namındaki büyük ulemaya mahsus olduğunu bildirmektedir. Ayrıca 1682 yılından beri kanun hilafına yeniçeri sayısının artırıldığından bahisle, rikâb-1 hümayun ağalarına yüz ellişer akçe ulufe ve muayyen birer zeamet miktarı arpalık, fakirliğe düşmekle darlık çeken bölük ağalarına yüz akçe ulufe ve on altışar yahut on yedişer bin arpalık yazılmasının kararlaştırıldığını belirtmektedir (Âli, 1997: 525-526, 559-561). Bir başka kayıtta, kendisini ziyaretten ayrılırken "Padişah hazretleri, efendimize yıllık olarak elli bin akçalık arpalık verdiler." diye bildiren Kanuni Sultan Süleyman'ın veziri İbrahim Paşa'ya, sabık Amasya müftüsü Seyyid İbrahim'in cevaben "Emir efendi, perhizde değilim ki arpa ekmeği yiyeyim, mescitten başka yere gitmem ki binek besleyeyim, arpa bize lazım olmaz.” şeklinde mukabelede bulunduğu, bunun üzerine vezir İbrahim Paşa'nın “....arpalık sadece bir deyimdir. Bundan maksat ancak hizmetçilerinizin, dervişlerinizin masraflarını karşılayacak bir para bir ödenek ayırmaktır." sözleriyle durumu açıkladığı rivayet olunmaktadır (Efendi, 1979: 235). Her iki durum bir arada değerlendirildiğinde, Osmanlı'da arpalığın uygulanma biçimindeki değişim ve buna bağlı olarak ihtiva ettiği anlamdaki farklılaşma daha anlaşılabilir hale gelmektedir.

Arpa parası anlamında kullanılan arpalığın bilhassa seyfiye ricaline verilmesine rağmen, tekâ'üdiye manasında ilmiye mensuplarına emekli olduklarında tevcih edildiği fakat 16 . yüzyılın ikinci yarısına kadar seyfiye ricaline aynı şekilde arpalık verildiğine ilişkin bir kayda rastlanılmadığı savunulmaktadır. Zira bu döneme kadar herhangi bir sancak, görevinden ayrılan veya emekli olan vezire ikta, ümeraya ise ocaklık suretiyle tevcih edilmektedir (Baltac1, 1991: 392-393). Daha önceleri başka isimler ve şekiller altında mevcut olan arpalığın, eldeki vesikalara göre 16. asırdan itibaren ordu ve saraya erkânına, ek tahsisat olarak, hayvanlarına yem ve hizmetkârlarına iaşe bedeli suretinde, aynı zamanda ve özellikle ilmiye ricaline tahsis edilirken, bilâhare kapsamının genişletildiğini kabul etmek gerektiği 
ifade edilmektedir (Gökbilgin, 1978, 594). Kendilerine arpalık tevcih edilen ilmiye ricali biri müderris diğeri kadı olmak üzere iki kısımda ele alınmaktadır. Bu sınıflandırma içerisinde müderrisler, müderrisi oldukları medresenin hâsılât-1 vakfiyyesiyle veya kendi servetleri ile geçinmekte; İslâm beldelerine tayin edilecek kadılar ise bu müderrislerin güzîdelerinden seçilip tayin olunmakta ve â'idât-ı şer'iyye ile hayatlarını idame ettirmektedirler. Kazanın maddi ve manevi mesuliyetini etraflıca düşünen ekser ulemanın meslek-i kazaya rağbet etmedikleri gibi kabul edenlerin geçici bir süreye bağlı kalınmasını ve eskiden olduğu gibi tedris ile iştigali arzu ettikleri görülmektedir. Müderris iken kadı olan bu kişilere belirli bir sürenin tamamlanmasından sonra bir beldenin hâsılât-ı emiriyyesinden arpalık namıla bir miktar meblağ verilmektedir (İnal, 1926: 279). Kısaca ifade etmek gerekirse, başlangıçta daha ziyade ilmiye mensuplarına verilen arpalığın, 16. yüzyılın ikinci yarısından sonra askeri zümreye kadar yaygınlaştırıldığı; hem görevde bulundukları sırada maaşlarına ek olarak hem de emeklilik hallerinde geçim vasıtası olarak tahsis edildiği anlaşılmaktadır (Manav, 2017: 3).

Ber vech-i arpalık bir sancağı idare eden zâta, kaldırılan hasları mukabilinde diğer bir sancak havale edildiği gibi hâlihazırda arpalık suretiyle bir sancağı idare eden vezire başka bir sancak da aynı şekilde arpalık olmak üzere tevcih kılınabilmektedir. Ayrıca arpalık yoluyla bir sancağa mutasarrıf olan zât, yine arpalık suretiyle bir başka sancağa mutasarrıf olan zât ile becayiş edilebilmekte, dilekçe üzerine bir sancak yine arpalık olarak bir başkasına havale edilebilmektedir (İnal, 1926: 278). 17. asrın sonlarına gelindiğinde sadrazamlıktan, sadaret kaymakamlığından ve serdarlıktan tekâ'üd edilenlere on-on iki yük akçe, hatta daha fazla haslar verildiği bilinmektedir. Daha sonraki tarihlerde, gerek vezir-i âzam gerek diğer vezir ve beylerbeylere herhangi bir mukataadan tekâ'üdiye olarak bir miktar para tahsis edildiği ya da bir bölgenin hâsılatının arpalık olarak verildiği görülmektedir (Uzunçarşılı, 1988: 166).

Şeyhülislam'a, sudûra, mevalîye ve bunların mazullerine de arpalık namiyle birer ikişer kaza tevcih edilmesinde akçenin değerindeki azalma ile makam sahiplerinin ziynet ve ihtişama meyillerinin esbab-ı maişetin artırılmasını gerektirmesi etkili sayılmaktadır. Bununla birlikte kendisine arpalık tevcih edilenler, o kazalara icra-yi ahkâm-1 kaza etmek [idari bölgenin hükümlerini yerine getirmek] üzere birer naip [vekil] göndermekte, hâsılatın bir miktarını verirken geriye kalanını da kendileri için kullanmaktadırlar. Pederlerinin veya mensup oldukları büyüklerin yardımıyla hak etmedikleri halde tarik-i tedrise dâhil olanlar mertebeleri aşıp kazaskerlik payesine kadar ulaştıklarından, devlet ve millete faydalarına şahit olunmadığı ve gelecekte de umulmadığı halde arpalıklarını küçük görmekte; kazalar erazil-i nüvvaba [rezil naiplere] ihale edildiğinden bunlar da ibadullahın başına belâ-yi mübrim kesilmektedir (İnal, 1926: 281). Esasen bu duruma henüz 1631'de dönemin padişahı IV. Murad'a sunulan bir risalede, boşalan dirliklerin kadim kanunlara aykırı olarak ileri gelenler ve vükela tarafından adamlarına ve akrabalarına verildiği; kiminin paşmaklık, kiminin arpalık yapılarak, kiminin vakıf, kiminin de vücudu sıhhatte olan nice kimselere emeklilik olarak verildiği sözleri ile dikkat çekilmektedir (Koçi Bey, 2007: 51-52). Nihayet, ulemaya verilen arpalığın dağıtım ve kullanım nizamının zamanla bozulması üzerine III. Selim döneminde çıkarılan bir ferman ile arpalık usulü sslah edilmeye çalışılmış; ilmiye mensuplarının bizzat arpalıklarının bulunduğu yerlere gitmesi, hasta ve ihtiyar olanların arpalıklarının ise iltizama verilmesi kararlaştırılmıştır (Baltacı, 1991: 393). Muahharen arpalık ismi kaldırılmış, tarik maaşı ihdas olunmuştur; bir ilmiye tekâ'üd sandığı kurularak tekâ'üd ve amelmande hakkı kazanmış memurin-i ilmiyeye ve vefatlarından sonra ailelerine bir miktar maaş tahsisi temin edilmiştir. İlân-1 meşrutiyetten sonra tarik maaşı da kaldırılarak ona bedel memuriyet maaşları uygun hadde yükseltilmiş ve mazulin-i ilmiyeye de memurin-i ilmiye gibi mazuliyet maaşı bağlanmıştır (İnal, 1926: 282). 


\section{SONUÇ}

Osmanlı İmparatorluğu'nda sosyal güvenlik sistemi temelinde; vakıf ve loncalar eliyle yürütülmektedir. Sosyal güvenlik sistemi içerisinde devlet görevlileri ile reaya ayrımı yapabilmek mümkün iken, devlet görevlilerinin gerek memuriyetleri sırasında gerekse emeklilikleri döneminde farklı uygulamalara tabi olduğunu söylemek mümkündür. İhtiyarlık veya sakatlık sebebiyle hizmet ve vazifesini terk ile istirahata çekilme anlamına gelen emeklilik, Osmanlı döneminde ku'ûd kökünden türetilen tekâ'üd kelimesi ile ifade edilmektedir. Tekâ'üd eden devlet görevlilerine sağlanan tahsisat ise bugünkü emekli maaşını karşılayacak biçimde tekâ’üdiye olarak nitelendirilmektedir.

Osmanlı İmparatorluğu emeklilik sisteminde içerisindeki tekâ'üdiye uygulamalarından biri, kendi içerisinde de türlü tatbik sahalarını ihtiva eden arpalık maaşıdır. Yapılan çalışmada, bahse konu arpalık uygulaması, İbnülemin Mahmud Kemal İnal'ın Tarih-i Osmanî Mecmuası'nda yayınlanan yazısından hareketle incelenmektedir. Araştırma soncunda, esasen 16. yüzyılın ikinci yarısından önce de başka isimler ve tevcih şekilleri ile var olduğu kabul edilen arpalık uygulamasının, bu tarihten sonra sosyal hayatı düzenlemek adına, günümüzdeki emekli maaşı anlamına karşılık gelecek şekilde kullanıldığı görülmektedir. Dolayısıyla yaygın kanaatin aksine benzer birkaç çalışmada da tespit edildiği gibi emeklilik sistemine yönelik birçok düzenlemenin Avrupalı devletlerden daha önce İmparatorluk sınırları içerisinde hayata geçirildiğini söylenebilir.

Arpalık verilmesi uygun görülen kişi mevcut durumda bir sancağı idare etmekle görevli vezir ise kendisine başka bir sancağın da yine arpalık yoluyla tevcihi mümkün olmaktadır. Arpalık suretiyle bir yerin gelirini elde eden kişiler arasında becayiş yapılmasına müsaade edilmekte, hatta dilekçeyle başvurulması durumunda arpalık hükmündeki bir sancak, bu hükmün geçerliliği korunarak bir başkasına verilebilmektedir. Uygulamadaki kolaylıklara ve sosyal düzenlemelere rağmen, arpalık uygulaması boyunca birtakım olumsuzlukların da yaşandığı gözlemlenmektedir. Bunların yaşanmasında etkili bir neden, babaları ve/veya yanlarında bulundukları büyüklerin yardımıyla hak etmedikleri rütbelere ulaşan fakat esasen millet ve devlet nezdinde bir faydası müşahede olunmayan kişilerin arpalık sahibi olmalarıdır. Zira bahse konu şahıslar arpalıklarını küçük görerek idarelerini vekillerine havale etmekte, vekilleri ise halkın başına bela kesilmektedir. Bu zorluklar arpalığın tahsisatında ve kullanımında ortaya çıkan bozukluklarla birleşince meşrutiyetin ilanının ardından yapılan düzenlemeler sonucu diğer memurlar gibi ilmiye sınıfına da maaş bağlandığı, arpalık uygulamasının tamamen kaldırıldığı anlaşılmaktadır.

\section{Kaynakça}

Akyıldız, H. (1999). Dünyada Sosyal Güvenlik Reform Alternatif Reform Arayışları. DË̈ Dergisi. 134(2). 197-214.

Aykanat, M. (2015). Osmanlı Sosyal Güvenlik Hukukunda Temel Kurumlar. (Doktora Tezi). Konya: Selçuk Üniversitesi Sosyal Bilimler Enstitüsü.

Baltac1, C. (1991). Arpalık. Türkiye Diyanet Vakfi Islam Ansiklopedisi. 3(392-393). İstanbul: İSAM.

Dilik, S. (1988). Sosyal Güvenliğin Tarihsel Gelişimi. Ankara Üniversitesi SBF Dergisi. 43(1). 41-80.
Doğan, N. (2013). Osmanlı İlmiye Sinıfi'nın Emekliliği Illmiye Tekaüd Sandı̆̆g'nın Kuruluşu ve Faaliyetleri. (Yayınlanmamış Yüksek Lisans Tezi). Yozgat: Bozok Üniversitesi Sosyal Bilimler Enstitüsü.

Efendi, H. S. (1979). Tacü't-Tevarih V. Haz. İ. Parmaksızoğlu. İstanbul: Milli Eğitim Basımevi.

Erdoğan, E. S. (2018). Avrupa Birliği Ülkeleri ve Türkiye'de Sosyal Güvenlik Harcamalarının Değerlendirilmesi. Ankara: Ankara Üniversitesi Avrupa Toplulukları Araştırma ve Uygulama Merkezi. 
Osmanlı Emeklilik Sistemi'nde Arpalık Uygulaması

Findley, C. V. (2011). Kalemiyeden Mülkiyeye Osmanlı Memurlarının Toplumsal Tarihi. Çev. Gül Çağalı Güven. İstanbul: Tarih Vakfı Yurt Yayınları.

Gökbilgin, T. (1978). Arpalık. MEB Islam Ansiklopedisi. (1592-595). İstanbul: Milli Eğitim Basımevi.

Güvercin, C. H. (2004). Sosyal Güvenlik Kavramı ve Türkiye'de Sosyal Güvenliğin Tarihçesi. Ankara Üniversitesi Tıp Fakültesi Mecmuast. 57(2). 89-95.

İnal, İ. M. K. (1926). Arpalık. Tarih-i Osmanî Mecmuast. 16(94). 276-283.

İpşirli, M. (2011). Tekaüt. TDV İslâm Ansiklopedisi. 40(340-341). İstanbul: TDV İslâm Araştırmaları Merkezi.

Keleş, H. (2006). Asâkir-i Mansûre-i Muhammediyye Kânûnnâmesi. Kastamonu Eğitim Dergisi. 14(1). 227-240.

Koçi Bey (2007). Koçi Bey Risaleleri. Haz. S. Çakmakcıoğlu. İstanbul: Kabalcı Yayınevi.

Kütükoğlu, M. S. (1991). Lütfi Paşa Âsafnâmesi (Yeni Bir Metin Tesisi Denemesi). İstanbul: Edebiyat Fakültesi Basımevi.

Manav, N. (2014). Mülkiye Tekaüd Sandığı'nın Kuruluşu ve Faaliyetleri (1880-1890). (Doktora Tezi). İstanbul: Marmara Üniversitesi Sosyal Bilimler Enstitüsü.

Mazuliyet Sandığı'nın Kuruluşu ve Kuruluşuna Yol Açan Sebepler (2017). Türkiyat Mecmuası. 27(1). 215-224.

Martal, A. (1999). Osmanlı İmparatorluğu'nda Emeklilik ve Buna İlişkin İlk Düzenlemeler. XIII. Türk Tarih Kongresi (1-11). Ankara.

XIX. Yüzyılda Osmanlı Ordusunda Tekaüdlük (2008). Feridun M. Emecen (Ed.). Eskiçă̆'dan Modern Çă̆'a Ordular-Oluşum, Teşkilât ve Işlev. (423-431). İstanbul: Kitabevi.

Orhan, S. (2015). Osmanlı Devleti'nde Tanzimat Sonrası Dönemde Sosyal Güvenlik Düzenlemeleri. İş ve Hayat. 1(1). 193-210.

Özcan, A. (2003). Kânunnâme-i Âl-i Osman (Tahlil ve Karşılaştırmalı Metin). İstanbul: Kitabevi.

Özcan, T. (1999). Osmanlı Toplumunda Sosyal Güvenlik Üzerine Bazı Gözlemler. Osmanlı $C$. V. (110-115). Ankara: Yeni Türkiye Yayınları.
Özger, Y. (2011a). Osmanlı Ordusunda Emeklilik Sistemi ve Askerî Tekaüd Sandiğ (1865-1923). İstanbul: IQ Kültür Sanat Yayıncilık.

Tanzimat Sonrası Osmanlı Kara Ordusunda Emeklilik İşlemlerine Dair Yapılan Düzenlemeler ve 1881 Tarihli Tekaüt Kanunnamesinin Tahlili. Selçuk Üniversitesi Türkiyat Araştırmaları Dergisi. (2011b).

Öztürk, M. (1983). Asakir-i Mansure-i Muhammediye Ordusundan Emeklilik ve İhraç. Birinci Askeri Tarih Semineri (Bildiriler II. s. 1-11). Ankara.

Pakalın, M. Z. (1993). Tarih Deyimleri ve Terimleri Sözlüğ̈̈ (C. II). İstanbul: MEB Yayınları.

Sami, Ş. (2017). Kâmûs-ı Türkî. İstanbul: İdeal Kültür\&Yayıncılık.

Şenocak, H. (2009). Sosyal Güvenlik Sistemini Oluşturan Bileşenlerin Tarihi Süreç Işı̆̆ında Değerlendirilmesi. Sosyal Siyaset Konferanslarl Dergisi. (56). 410-468.

Tabakoğlu, A. (2005). Iktisat Tarihi Toplu Makaleler I. İstanbul: Kitabevi.

Türkiye İktisat Tarihi (2014). İstanbul: Dergâh Yayınlar1.

Talas, C. (1955). Sosyal Güvenlik Meselemiz. Sosyal Siyaset Konferansları Dergisi. (7). 84-99.

Türkal, H. (1999). Türk Sosyal Güvenlik Sistemi (T.C. Emekli Sandiğı'na Özel Bir Bakış). (Doktora Tezi). İstanbul: Marmara Üniversitesi Sosyal Bilimler Enstitüsü.

Uzunçarşılı, İ. H. (1988). Osmanlı Devleti'nin Merkez ve Bahriye Teşkilatı. Ankara: Türk Tarih Kurumu Basimevi.

Ünal, U. (2006). Sultan Abdülaziz Devri Osmanlı Kara Ordusu (1861-1876). (Doktora Tezi). Ankara: Gazi Üniversitesi Sosyal Bilimler Enstitüsü.

Yazgan, T. (1972). Sosyal Güvenlik Kavramı. Sosyal Siyaset Konferanslarl Dergisi. (24). 191-208. 
